\title{
Miten yrittäjiä kasvatetaan?
}

\author{
y \\ Yrittäjyys on määritelty yhdeksi tulevien sukupolvien \\ avaintaidoista. Yrittäjyyskasvatuksen mittaristo näyttäytyy \\ lähemmin tarkasteltuna välineenä, jonka avulla \\ yrittäjyydestä pyritään luomaan uusi työmarkkinoiden \\ toimintamalli.
}

YRITTÄJÄMÄISEN AJATTELUTAVAN katsotaan olevan tulevien sukupolvien keino löytää paikkansa sekä luoda tilansa ja tapansa toimia globalisoituneessa maailmassa. Euroopan unioni on asettanut yrittäjyyden yhdeksi kansalaistensa avaintaidoista, jonka avulla voidaan turvata talouden kasvu. (Euroopan komissio 2003; Opetusministeriö 2004.)

Julkilausumissa sisäisen ja ulkoisen yrittäjyyden tavoittelun korostamisen voidaan tulkita tarkoittavan samalla työelämän epävarmuuden kyseenalaistamatonta hyväksymistä sekä yrittäjämäisen toiminnan tavoittelua työmarkkinoilla (ks. Gibb 2011, 151-152). Yrittäjyyskasvatuksen onnistumisen mittaaminen näyttäytyy edellä olevien julkilausumien valossa tavoiteltavana.
Pohdin seuraavassa yrittäjyyskasvatuksen tavoitteita ja problematisoin hieman, miksi yrittäjyyskasvatuksessa onnistumista pyritään varmentamaan mittaamalla.

Sarasvathy ja Venkataraman $(2011,130)$ haastavat muotoilemaan yrittäjyyden "inhimillisten toimien metodiksi, jossa on yhtymäkohtia yleisesti demokratiaan". Märitelmällä tavoitellaan siis lähestymis- ja hallintatapaa, jossa yrittäjyyskasvatuksen periaatteita, suuntaa ja mittaristoja arvioidaan uudelleen. Uuden määritelmän muotoiluun osallistuu mainiosti myös maailmanlaajuisesti ainutlaatuinen, Opetushallituksen ja Lappeenrannan teknillisen korkeakoulun sekä Kerhokeskus ry:n vuonna 2008 aloittama hanke yrittäjyyskasvatuksen mittariston kehittämisestä. 
Mittariston tavoitteena on auttaa opettajia kehittymään työssään yrittäjyyskasvattajina sekä mitata yrittäjyyskasvatuksessa onnistumista (Yrittäjyyskasvatuksen mittaristo). Mittaristo voidaan kriittisessä lähestymistavassa hahmottaa foucault'laisen valta-analytiikan kautta, jolloin se hahmotetaan poliittisena toimijana (Harni 2015). Ajatus mittariston poliittisesta toimijuudesta ei ole vieras yrittäjyyden teoreetikoidenkaan keskuudessa: Sarasvathy ja Venkataraman (2011) näkevät myönteisenä ja suorastaan yrittäjyyden keskeisenä ilmiönä yrittäjyyden yhtymäkohdat poliittiseen toimijuuteen.

\section{YRITTÄJYYS JA VAIHTOSUHDE}

Monet opettajat ovat vieroksuneet yrittäjyyden opettamista osittain siksi, että yrittäjyyskasvatus mielletään uusliberalistisen arvomaailman vahvistamiseksi arkisessa opetustyössä. Nykykäsityksemme mukainen hyvä opetus (mikäli sille tarjotaan tarvittava tila, vapaus ja resurssit) on jo sellaisenaan luovuuteen ja yrittäjyyteen kannustavaa. Onkin ilmeistä, että yrittäjyyskasvatuksen kritiikkiin nivoutuu laajempi yhteiskunnan, työelämän ja työmarkkinoiden muutos. Sennett (2002) on kuvannut tätä asenteelliseksi muutokseksi, jossa työntekijän sitoutuminen ei enää ole tavoiteltavaa, kun työ on luoteeltaan projektimaista ja siten jatkuvassa muutoksessa. (ks. myös Ehrenreich 2006).

Yrittäjyyskasvatuksen ideologian jalkautumisen lomassa keskustelu työelämän muutoksesta on kaikunut kumeasti myös kotoisissa puheenvuoroissamme. Näistä mainittakoon Siltalan (2004) Työelämän huonontumisen lyhyt historia, Julkusen (2008) Uuden työn paradoksit sekä Suorannan (2009) Halvennettu työ, jotka peilaavat tämän päivän työtä laajemmin työn historiaan. Lisäksi on mainittava erityisesti yrittäjyyskasvatusta kritisoiva Komulaisen, KeskitaloFoleyn, Korhosen ja Lappalaisen (2010) toimittama Yrittäjyyskasvatus hallintana, joka antaa hyvän näkökulman myös yrittäjyyskasvatuksen mittariston kritiikkiin tarkasteluun ja haastaa pohtimaan kumpi on hallinnan kohteena, opetettava aines vai opettaja.

Yrittäjyyskasvatuksen kritiikkiä kehystää Sennettin (2002; 2007) esittämä kuvaus nykyajan työelämästä ja uuden kapitalismin kulttuurista. Sennett (2002) määrittelee "ihmisen luonnetta kuluttaviksi" tekijöiksi erityisesti joustamisen, riskinoton ja ajelehtimisen. Nämä piirteet liitetään usein yrittäjyyteen. Sennettiin (2002; 2007), Julkuseen (2008) ja Siltalaan (2004) nojautuen voikin sanoa, että työelämän muutos ja tietotyö ovat tuottaneet työmarkkinoille uuden järjestäytymättömän luokan, jolla ei ole omaa ammattiyhdistyksellistä viitekehystä eikä järjestäytymisen kulttuuria. Olemmeko siis työmarkkinoiden siirtymätilanteessa - vastaavassa tilanteessa, jossa olimme esiteollisessa vaiheessa (ks. myös Suoranta 2009)?

Yrittäjämäisen ajattelun puolustuksen voisikin paradoksaalisesti hakea Siltalan (2004) teoksesta, jossa hän toteaa "työn vaihtosuhteen" huonontuneen: "paljonko täytyy tehdä ja millaisilla ehdoilla saadakseen säälisen elämän?" (emt., 7-10). Gibb (2011, 151) esittää, että voimaantuminen on yrittäjämäisen toimijuuden mahdollistaja ja näkee yrittäjämäisen ajattelutavan olevan ratkaisumalli kaikkeen siihen, mitä uutta kapitalismia kritisoiva suuntaus epäilee. Gibbin (2011, 154-155) mukaan "yrittäjämäinen ajattelutapa edistää oppimista", toimivan kasvatuksen tukena, mutta muistuttaa argumentin olevan samalla peruste hyökkäyksiin yrittäjyyskasvatusta vastaan.

Poleemisuutta vahvistaen voisi väittää, että yrittäjyyskasvatuksen mittaristo ei helli korkeasti koulutetun suomalaisen opettajankunnan ammattiylpeyttä. Mittaristo kun helposti ohjaa suorittamaan annettua muotoa - sitä saa mitä mittaa. Olisiko yrittäjyyskasvatusta mahdollista kehittää jatkossa erityisesti kasvatustieteen eetosta kunnioittavassa hengessä, ymmärtäen kasvatustieteen päälinjojen ja yrittäjyyskasvatuksen yhtymäkohdat?

\section{OPETETTAVUUDEN DILEMMA}

Yrittäjyyden teoriapainotteisen opetuksen tavoitteena on opettaa tietoa yrittäjyydestä eli vastata kysymyksiin miksi (vahvistus), mitä (faktat) ja kuinka (pehmeät taidot) (ks. esim. Haase \& Lautenschläger 2010). Toisaalta yrittäjyyskasvatuksen piilo-opetussuunnitelma lienee kiistatta pyrkimys muovata yrittäjämäisiä yksilöitä. Opetuksen käytössä olevan mittariston "opeta, mittaa, kehitä" -malli voidaan nähdä opettajuuden hallintana ja harjaantumisena yrittäjä- 
mäiseen tapaan, jonka voisi arvella välittyvän lopulta kaikkeen opetukseen.

Pittawayn, Hannonin, Gibbin ja Thompsonin (2009) mukaan yrittäjyyskasvatuksessa on saatettu unohtaa käytännön ja kokemuksen opettamisen merkitys. Yrittäjyyskasvatukseen siis liittyy haaste siitä, miten seuraavassa listatut yrittäjyyden elementit voidaan koulutuksessa siirtää:

1. Yrittäjämäisten kyvykkyyksien, taitojen ja asenteiden kehittyminen - voidaanko koulutuksessa tuottaa todellisuuteen verrattavia innovaatioita, mahdollisuuden löytämis- ja hyödyntämistilanteita sekä yrittäjyyden arkea?

2. Yrittäjyyteen liittyvien arvojen välittyminen koulutuksessa - miten voidaan tuottaa yrittäjämäistä vapauden ja itsenäisyyden tunnetta?

3. Yrittäjäuraan motivointi - missä määrin koulutus motivoi ja pystyy motivoimaan kohti yrittäjüuraa?

4. Arjen haasteiden hallinta - miten tuottaa arkeen verrattavaa oppimista liiketoiminnan aloittamisesta sekä esimerkiksi tuotteiden kehittämisestä, markkinoiden löytämisestä ja hinnoittelusta?

5. Suhdetoiminnan hallinta - miten tuottaa osaamista johtamisesta sekä osakkaiden, rahoittajien ja hallituksen jäsenten kanssa toimimisesta? (Mt. 77.)

Edellä listatut elementit kannustavat yhä uudestaan pohtimaan, onko yrittäjyyskasvatuksen päätehtävänä yrittäjyyteen liittyvien haasteiden ja mahdollisuuksien valottaminen koulutuksen avulla, eli yrittäjyyteen valmistaminen. Kysymys vastaa Pittawayn ym. $(2009,90)$ pohdintaa siitä, millainen yrittäjyyskasvatuksen ydinfilosofian tulisi olla.

Yrittäjyyskasvatuksen mittaristossa yrittäjyys nähdään kokonaisvaltaisena tapana osoittaa mahdollisuuksia ja ratkoa ongelmia. Yrittäjyyskasvatuksen mittariston teemat ovat:

1. Yrittäjyys ja yrittäjyyskasvatus - luovuus ja innovatiivisuus, epävarmuuden sieto ja riskinotto.

2. Pedagogiset ratkaisut - opettaja oppimisen mahdollistajana, yhteistoiminnallinen oppiminen.

3. Toimintakulttuuri - yrittäjämäinen toimintatapa ja tulevaisuusorientaatio.

4. Oppimisympäristö - yhteisöllisyys, työelämäyhteydet, valinnaisuus ja kerhotoiminta.

5. Toiminta verkostoissa - järjestö-, yritys- ja oppilai- tosyhteistyö. (Yrittäjyyskasvatuksen mittaristo, 4.) Yrittäjyyskasvatuksen mittariston teemat ovat suorastaan hämmästyttävän rinnasteisia Pittawayn ym. (2009) esityksen kanssa. Ensisilmäyksellä mittaristo näyttää kuitenkin mittaavan pikemminkin opettajan suoritusta kuin yrittäjyyskasvatusta.

Yrittäjyyskasvatuksen mittariston perusteet palautuvat "opetettavuuden dilemmaan" eli kysymykseen siitä, mitä pedagogiikassa tulisi painottaa, jotta pystyttäisiin rakentamaan ja vahvistamaan yrittäjyyttä (Haase \& Lautenschläger 2010). Opetettavuuden dilemman määrittelyssä ja purkamisessa yliopistoilla ja yrittäjyydestä tehtävällä tutkimuksella onkin merkittävä rooli (Raposo \& do Paco 2010). Akateemisen tutkimuksen merkitys korostuu myös arvioitaessa, miten ympäristö vaikuttaa asenteisiin ja edistää yrittäjyyden aloittamista, ja miten nämä eri olosuhteet vaikuttavat yrittäjyyskasvatukselle asetettaviin tavoitteisiin ja haasteisiin (Giasomin \& Janssen \& Pruett 2010).

Crick (2011) on pohtinut pitkittäisessä tapaustutkimuksessaan, millaisia tavoitteita yrittäjyyden kouluttamiseen eri oppiasteilla tulisi liittyä. Hän toteaa, että yrittäjän tarpeet tiedolle ja koulutukselle vaihtelevat yrittäjän iän mukaan. Myös Kirby (2004) on pahoitellut, että monesti uuden yrityksen perustamisessa painotetaan liiketoimintasuunnitelmaa ja johtamista sen sijaan, että tavoiteltaisiin yksilön kykyä hallita luovuutta ja muutoksia (ks. myös Canina \& Palacios \& Devece 2010).

Yrittäjyyskasvatuksen keskeisenä tehtävänä näyttäytyy olemassa olevien (yrittäjyys)mahdollisuuksien löytäminen ja hyödyntäminen (ks. myös Shane \& Venkataraman 2000). Oma kysymyksensä on, koskettaako akateemisissa juhlapuheissa korostettu innovaatioiden löytäminen ja hyödyntäminen pienyrittäjää, vai jääkö se etäiseksi teoreettiseksi pohdinnaksi. Kysymys jättää myös tyystin pohtimatta yrittäjyyskasvatuksen yhteiskunnallisen ja siten myös poliittisen tehtävän talouskasvun eli nykymuotoisen kulutusyhteiskunnan jatkuvuuden turvaajana.

Draycott ja Rae (2011, 128-130) painottavat yrittäjyyden kokemuksellisuuteen perehdyttämistä. He viittaavat Cairdin (1992) tekemään jakoon yrittäjämäisistä taidoista (persoonaan liittyvät ominaisuudet, vuorovaikutustaidot, johtamistaidot, analyyttiset 
taidot, uran edistämistaidot, tiedot ja osaaminen sekä asenteet). Jaottelu nojautuu hyvinkin perinteiseen yrittäjämäisen ajattelun määrittelyyn.

Draycottin ja Raen $(2011,130)$ mukaan kuitenkin erityisesti kouluissa tapahtuvassa yrittäjyyskasvatuksessa tarvitaan myös käytännöllistä kokemusta ja vahvistusta pehmeimmille yrittäjyystaidoille, kuten yhteistyölle, ongelmanratkaisulle ja suunnittelulle. He ovat tutkineet 14-19-vuotiaiden koululaisten näkemyksiä yrittäjyydestä. He jakavat yrittäjyyskasvatuksen tavoitteet kolmeen ryhmään:

1. Henkilöön liittyvät eli itsetuntemuksen, tehokkuuden ja innovatiivisuuden kehittymisen tavoitteet.

2. Tilanteisiin liittyvät eli käytännölliseen luovuuteen, kuten oppimiseen ja yrittäjämäiseen toimintaan liittyvät tavoitteet.

3. Talouteen liittyvät tavoitteet sekä lisäarvoa (esimerkiksi esteettisyys, henkisyys, ympäristöön liittyvät) tuottavat tavoitteet. (Draycott \& Rae 2011, 137-138.)

\section{YRITTÄJÄPERSOONAN MYSTIFIOINTI}

Yrittäjyyskasvatuksen mittaristo on tervetullut apuväline hälventämään yrittäjäpersoonaan perinteisesti liitettyä mystiikkaa. Uskallan sanoa, että yrittäjyyskasvatuksessa piilee kuitenkin "menestyksen avain", koska yrittäjyyteen koulutetuilla henkilöillä näyttäsi olevan suurempi todennäköisyys hakeutua yrittääksi jo nuorena. Koulutuksella on myönteinen vaikutus yrittäjän kykyyn hahmottaa ja hallita ympäristöään. (Pickernell \& Packham \& Jones \& Miller \& Thomas 2011, 183-184; 197; ks. myös Smith \& Patton 2011.) Myös Duening $(2010,1)$ on Mitchellin ym. (2007) ajatuksiin nojautuen korostanut, että kognitiiviset taidot ovat merkittävä erottelija siinä, kuinka yrittäjä menestyy. Duening $(2010,2)$ korostaa, että yrittäjyyskasvatuksen parissa toimivan opettajan tavoitteena on yrittäjämäisen käytöksen opettaminen. Haasteena tälle toteamukselle voidaan esittää, että Gardnerin $(2007,3)$ määrittelemien ja seuraavassa listattujen toiminnallisen aikuisen piirteiden ja arvojen opettaminen ei liene parhaallekaan yrittäjyyskasvattajalle yksinkertaista:

1. Kurinalainen mieli, joka tietää miten ratkoa monimutkaisiakin ongelmia.
2. Syntetisoiva mieli, joka pystyy keräämään, yhdistelemään ja hyödyntämään erilaista on informaatiota.

3. Luova mieli, joka pystyy tuottamaan uutta tapaa ajatella.

4. Kunnioittava mieli, joka mahdollistaa menestyksellisen toimimisen erilaisuudessa ja moninaisuudessa.

5. Eettinen mieli, joka vaalii kunniallisuutta ja arvoja. (Mt, 3.)

Gardner (2007) on esittänyt yrittäjyyskasvatukseen kätkeytyvän kahtalaisen haasteen. Yhtäältä tavoitteena on akateemisten tietojen ja taitojen kartuttaminen, sekä toisaalta myös persoonaan liittyvien piirteiden hiominen ja kehittäminen. Pruett, Shinnar, Toney, Llopi, ja Fox (2009) ovat osoittaneet, että opiskelijoiden näkemykset yrittäjyyden motivaatiosta ja esteistä ovat eri kulttuureissa suhteellisen yhtäläiset. Keskeinen yrittäjyyden aloittamiseen vaikuttava tekijä näyttää olevan henkilön usko omiin kykyihinsä yrittäjänä.

Pruettin ym. (2009) sekä Drnovsekin, Wincentin ja Cardonin (2010) mukaan yrittäjyyskasvatuksessa tulisi korostaa myös yrittäjyyden sosiokognitiivisia, psykologiskognitiivisia ja eettisiä kysymyksiä.

\section{TULEVAISUUDEN TYÖKULTTUURIA RAKENNETAAN TÄMÄN PÄIVÄN KOULUISSA}

Sarasvathy ja Venkataraman (2011) ovat määritelleet yrittäjyyden metodiksi, joka muodostuu kysymysten sarjasta: "Mitä yrittäjä tekee, miten markkinat muodostuvat ja onko yrittäjä vapaiden markkinoiden instrumentti? Kuka on potentiaalinen yrittäjä ja miten yrittäjä kipuaa talouden ja teknologian kehityksen yli luoden pehmeitä arvoja kuten sosiaalista innovaatiota ja inhimillistä kehitystä? Miten sosiaaliset yritykset eroavat tavanomaisista yrityksistä ja miten voitaisiin kannustaa sosiaalisten ongelmien ratkaisuihin investoimista?" Kysymyslista on mielenkiintoinen ja ilmentää Sarasvathyn ja Venkataramanin $(2011,123)$ tavoitetta liittää yrittäjyys demokratiaan ja sosiaaliseen toimintaan. Sarasvathy ja Venkataraman (2011, 123) arvuuttelevat, miksi ajattelemme, että investoimme yrityksiin ja annamme hyväntekeväisyyteen. Näin kysymällä yrittäjyyskasvatuksen voi ajatella laajennettavan sellaisillekin alueille, joissa sitä ei aiemmin ole tavattu. 
Olen käsitellyt yrittäjyyskasvatuksen ideaalia pyrkien hienovaraisesti avaamaan sitä toimintakenttää ja arvomaailmaa, jossa yrittäjyyskasvatuksen teoria syntyy ja kehittyy. Yrittäjyyskasvatuksen laajemmassa katsannossa näyttää lopulta siltä, että yrittäjyydestä pyritään luomaan uusi työmarkkinoiden toimintamalli, jonka iskostamiseen tarjotaan valmennusta perusopetuksessa toimiville opettajille. Yrittäjyyskasvatuksen mittaristo voidaan siis nähdä opettajan oman työn ja siinä kehittymisen apuvälineenä.

Yrittäjyyskasvatuksen mittariston kritiikki kohdistuu sen kätkettyyn tavoitteeseen, joka näyttäytyy poliittisen hallinnan välineenä. Koulutusta koskevat päätökset ovat aina poliittisia, vaikka ne arjessa näyttäisivätkin poliittisesta juurestaan erkaantuneilta.
Kirsi Saurén

KT, KTM, yliopisto-opettaja

Jyväskylän yliopisto

\section{LÄHTEET}

Caird, S. (1992). Problems with the identification of enterprise competencies and the implications for assessment and development. Management and Education Development 23(1), 6-17.

Canina, L., Palacios, D. \& Devece, C. (2010). Management theories linking individual and organizational level analysis in entrepreneurship research. International Entrepreneurship Management Journal 22, December 2010.

Crick, D. (2011). Enterprising individuals and entrepreneurial learning. A longitudinal case history in the UK tourism sector. International Journal of Entrepreneurial Behaviour \& Research 17(2), 203-218.

Draycott, M. \& Rae, D. (2011). Enterprise education in schools and the role of competency frameworks. International Journal of Entrepreneurial Behaviour \& Research, 17(2), 127-145.

Drnovsek, M., Wincent, J. \& Cardon, M. S. (2010). Entrepreneurial self-efficacy and business startup: developing a multi-dimensional definition. International Journal of Entrepreneurial Behaviour \& Research, 16(4), 329-348.

Duening, T. D. (2010). Five Minds for the Entrepreneurial Future: Cognitive Skills as the Intellectual Foundation for Next Generation Entrepreneurship Curricula. Journal of Entrepreneurship 19(1), 1-22.

Ehrenreich, B. (2006). Petetty keskiluokka. Alkuteoksesta Bait \& Switch (2005) The (Futile) Pursuit of American Dream. Suom. N. Vilokkinen. Tampere: Vastapaino.
Euroopan komissio (2003). Yrittäjyyden vihreä kirja. http://www.yrittajakoulu.fi/tietotori/Liikanen_ EU_\%20green.paper.fi.pdf. (Tarkistettu 17.10.2015.)

Gardner, H. (2007). Five Minds for the Future. Cambridge MA: Harvard Business School Press.

Giacomin, O., Janssen, F., Pruett, M., Shinnar, R. S., Llopis, F. \& Toney, B. (2010). Entrepreneurial intentions, motivations and barriers: Differences among American, Asian and European students. International Entrepreneurship Management Journal, 27. March 2010.

Gibb, A. (2011). Concepts into practice: meeting the challenge of development of entrepreneurship educators around an innovative paradigm. The case of the International Entrepreneurship Educators' Programme (IEEP). International Journal of Entrepreneurial Behaviour \& Research 17(2), 146-165.

Haase, H. \& Lautenschläger, A. (2010). The 'Teachability Dilemma' of entrepreneurship. International Entrepreneurship Management Journal, 30. March 2010.

Harni, E. (2015). "Opeta, mittaa, kehitä" Yrittäjyyskasvatuksen mittaristo hallinnallisena artefaktina. Aikuiskasvatus 35(2), 99-110.

Julkunen, R. (2008). Uuden työn paradoksit. Keskusteluja 2000-luvun työprosess(elista. Tampere: Vastapaino.

Kirby, D.A. (2004). Entrepreneurship education: can business schools meet the challenge? Education and Training, 46(8/9), 510-519. 
Komulainen, K., Keskitalo-Foley, S., Korhonen, M. \& Lappalainen, S. (toim.) (2010). Yrittäjyyskasvatus hallintana. Tampere: Vastapaino.

Mitchell, R.K., Busenitz, L.W., Bird, B., Gaglio, C.M., McMullen, J.S., Morse, E.A. \& Smith, J.B. (2007). The central question in entrepreneurial cognition research 2007. Entrepreneurship Theory \& Practice $1-28$.

Opetusministeriö (2004). Yrittäjyyskasvatuksen linjaukset ja toimenpideohjelma. http://www.minedu.fi/export/ sites/default/OPM/Julkaisut/2004/liitteet/opm_169_ opm18.pdf?lang=fi (tarkistettu 17.10.2015)

Pickernell, D., Packham, G., Jones, P., Miller, C. \& Thomas, B. (2011). Graduate entrepreneurs are different: they access more resources? International Journal of Entrepreneurial Behaviour \& Research, 17(2), 183-202.

Pittaway, L., Hannon, P. \& Gibb, A. \& Thompson, J. (2009). Assessment practice in enterprise education. International Journal of Entrepreneurial Behaviour \& Research, 15(1), 71-93.

Pruett, M. \& Shinnar, R., Toney, B., Llopi, F. \& Fox, J. (2009). Explaining entrepreneurial intentions of university students: a cross-cultural study. International Journal of Entrepreneurial Behaviour \& Research, 15(6), 571-594.

Raposo, M. \& do Paço, A. (2010). Special issue: entrepreneurship and education - links between education and entrepreneurial activity. International Entrepreneurship Management Journal, 7 April 2010.

Sarasvathy, S. D. \& Venkataraman, S. (2011). Entrepreneurship as Method: Open Questions for an Entrepreneurial Future. Entrepreneurship Theory and Practice, January 2011, 113-136.

Sennett, R. (2002). Työn uusi järjestys. Miten uusi kapitalismi kuluttaa ihmisten luonnetta. Alkuteoksesta The Corrosion of Character (1999). Suom. E. Kivinen \& D. Kivinen. Tampere: Vastapaino.

Sennett, R. (2004). Kunnioitus eriarvoisuuden maailmassa. Alkuteoksesta Respect in a World on Inequality (2003). Suom. K. Koskinen. Tampere: Vastapaino.

Sennett, R. (2007). Uuden kapitalismin kulttuuri. Alkuteoksesta The Culture of New Capitalism (2006). Suom. K. Koskinen. Tampere: Vastapaino.

Shane, S. \& Venkataraman, S. (2000). The Promise of Entrepreneurship as a Field of Research. Academy of Management Review, 25(1), 217-226.

Siltala, J. (2004). Työelämän huonontumisen lyhyt historia. Helsinki: Kustannusosakeyhtiö Otava.

Smith, A. M. J. \& Paton, R. A. (2011). Delivering enterprise. A collaborative international approach to the development, implementation and assessment of entrepreneurship. International Journal of Entrepreneurial Behaviour \& Research 17(1), 104-118.

Suoranta, A. (2009) Halvennettu työ. Tampere: Vastapaino.

Yrittäjyyskasvatuksen mittaristo = Yrittäjyyskasvatuksen mittariston opaskirja. http://developmentcentre.lut.fi/ files/muut/Yrittajyyskasvatuksen_mittaristo_NETTI. pdf (tarkistettu 17.10.2015) 